\title{
A rare case of chronic ectopic pregnancy mimicking ovarian tumor: a diagnostic dilemma
}

\section{Maureen Prativa Tigga*, Salil Bindu Chakraborty, Jayanta Ray, Sourish Debbarma, Amulya Debbarma}

\begin{abstract}
Department of Obstetrics \& Gynaecology, Agartala Government Medical College \& GB Pant Hospital, Agartala, Tripura, India
\end{abstract}

Received: 07 April 2015

Accepted: 09 May 2015

\section{*Correspondence:}

Dr. Maureen Prativa Tigga,

E-mail: maureentigga@gmail.com

Copyright: () the author(s), publisher and licensee Medip Academy. This is an open-access article distributed under the terms of the Creative Commons Attribution Non-Commercial License, which permits unrestricted non-commercial use, distribution, and reproduction in any medium, provided the original work is properly cited.

\begin{abstract}
Clinical presentation of chronic ectopic pregnancy is often perplexing. The diagnosis becomes difficult due to paucity of classical signs and symptoms and at times the relevant investigations turn out to be falsely negative. We present one such case, reporting to our hospital which serves the underprivileged North Eastern population of India. The low resource set up led to limitations in our approach and here we point out the factors which led to the diagnostic dilemma. We are reporting this case because similar challenges can be faced by other clinicians who are working in set up like ours.
\end{abstract}

Keywords: Chronic ectopic pregnancy, Hematosalpinx, Ovarian tumor

\section{INTRODUCTION}

Chronic ectopic pregnancy poses a challenge because of its subtle symptoms and wide range of clinical presentation. The true incidence of chronic ectopic is not known with certainty, however some studies report it as $6-20 \%$ of all ectopic pregnancies. ${ }^{1-4}$ Rarely it can present as a large hematosalpin $x^{5,6}$ or a large abdominopelvic lump mimicking an ovarian tumor. ${ }^{4}$ One such case is being reported here.

\section{CASE REPORT}

A 31 year old illiterate woman, hailing from rural interiors of Tripura and belonging to poor socioeconomic strata, had history of irregular bleeding per vaginum since 2 months with associated pain abdomen. She was referred from a district hospital accompanied with an ultrasonography (USG) report suggestive of molar pregnancy.

There was no clear history of preceding amenorrhea and she had irregular bleeding per vaginum for the past 2 months. She was parity 3 with 3 living children, all delivered vaginally. She also had a spontaneous miscarriage at 3 months amenorrhea 6 years back, for which she underwent dilatation and curettage. Her last child birth was 3 years back. There was no history suggestive of prior pelvic infection or endometriosis. She was a non-smoker and was not using any contraceptive methods.

On examination, mild pallor was present, pulse rate was $80 / \mathrm{min}$ and her blood pressure was $120 / 70 \mathrm{~mm}$ of $\mathrm{Hg}$. A solid mass corresponding to 18 weeks uterus, with restricted mobility was palpated per abdominally whose lower margin could not be reached. Speculum 
examination revealed minimal bleeding through external os and vagina was healthy. On bimanual examination the mass was felt abdominally and due to voluntary guarding by the patient the uterus could not be palpated distinctly. There was fullness in the right fornix and pouch of Douglas but there was no cervical motion tenderness.

Urine test for human chorionic gonadotropin (hCG), also called the Urine Pregnancy Test (UPT) was negative. Being mindful of the USG report available with the patient suggesting molar pregnancy, where UPT is often negative in case of very high $\beta$-hCG concentration due to the phenomenon of "high dose hook effect", 7 a serum $\beta$ $\mathrm{hCG}$ along with thyroid profile, chest $\mathrm{x}$-ray and a repeat USG were carried out. Patient was administered antibiotics and analgesics. Other investigations for pre anesthetic work up were done.

The repeat USG report revealed a large right complex ovarian mass with a normal uterus and normal left ovary. Serum $\beta$-hCG was found to be $2.53 \mathrm{IU} / \mathrm{ml}$ (reference range $<1 \mathrm{IU} / \mathrm{ml}$ in non-pregnant state). Thyroid profile and chest X-ray were normal. Her other blood investigations were within normal limits. A repeat clinical examination (after alleviating patient's anxiety and voluntary guarding), suggested a huge right adnexal mass and a normal sized uterus which was adherent to the mass.

In the light of fresh USG report and repeat clinical examination, there was possibility of endometrioma and ovarian mass, therefore further investigations were carried out which were as follows: Cancer antigen (CA125): $116 \mathrm{IU} / \mathrm{ml}$ (normal <35 IU/ml); carcinoembryonic antigen (CEA): $2.2 \mathrm{ng} / \mathrm{dl}$ (normal $<2.5$ $\mathrm{ng} / \mathrm{dl}$ ); Alpha feto protein (AFP): 10ng/dl (normal <10 $\mathrm{ng} / \mathrm{dl}$ ). Exploratory laparotomy was performed which revealed dense adhesions between bowel loops and omentum obscuring the right fallopian tube and ovary. On releasing the adhesions, lo and behold! A large hematosalpinx of $10 \times 8 \mathrm{~cm}$ size was exposed. A normal right ovary was identified posterior to this mass. Right salpingectomy was performed and the histopathological examination of the specimen showed chorionic villi confirming the diagnosis of ectopic pregnancy.

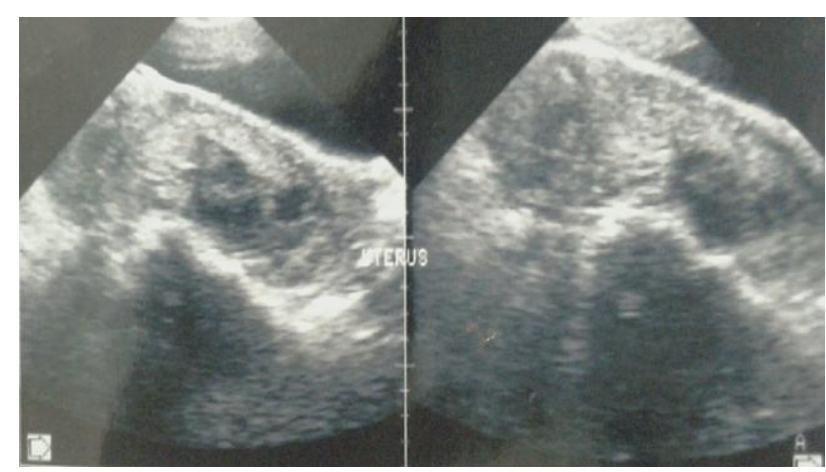

Figure 1: USG scan from district hospital suggesting molar pregnancy.

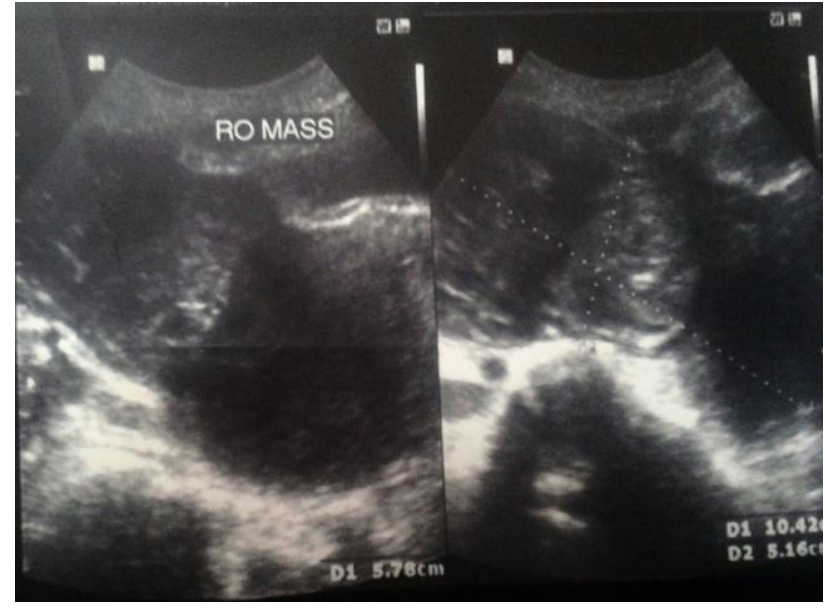

Figure 2: Repeat USG scan suggesting right complex ovarian mass.

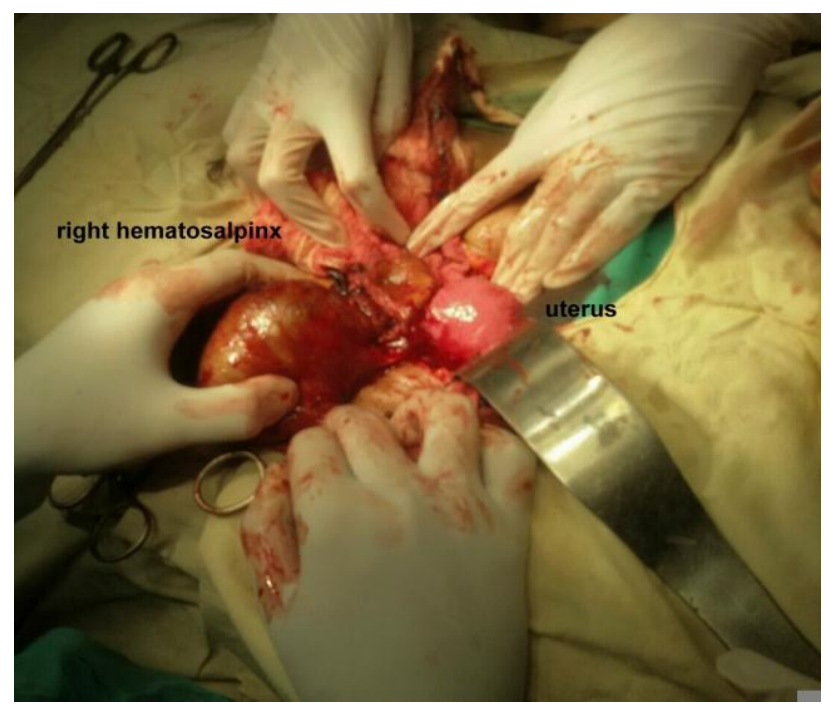

Figure 3: Clinical photograph showing a large right hematosalpinx with normal sized uterus.

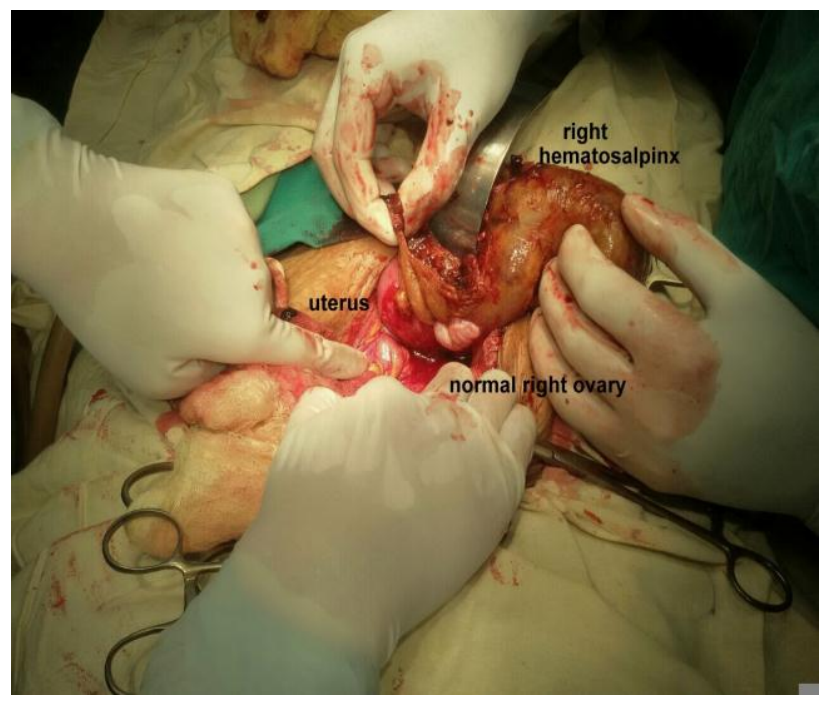

Figure 4: Clinical Photograph showing a normal right ovary posterior to the hematosalpinx. 


\section{DISCUSSION}

Chronic ectopic pregnancy remains an enigma for the gynaecologist as it has a wide spectrum of clinical presentation. Chronic ectopic pregnancy results from small recurrent bleed into pelvic peritoneal cavity which forms an organized clot in between the pelvic structures which is called pelvic hematocele. ${ }^{2}$ Sometimes the bleeding is confined to the tube itself with no peritoneal communication leading to the formation of a hematosalpinx..$^{6,8}$

The aforementioned entities incite the formation of adhesions with the adjacent structures and these can clinically present as a pelvic or an abdominal lump as seen in our case. Because the signs and symptoms of chronic ectopic pregnancy are non-classical, its diagnosis becomes a dilemma.

The inability to arrive at a definite diagnosis in our case was because the USG report which the patient brought with herself from the district hospital was suggestive of molar pregnancy, and the initial finding of an 18 week uterus with a negative urine $\beta$-hCG test added more to the predicament.

Further, as the patient came from a very poor background from the difficult terrains of Tripura, she could not afford all the tests advised to her. So with best available and affordable modalities she was further investigated and the subsequent USG scan suggested a right complex ovarian mass. The CA125 level was found to be $116 \mathrm{IU} / \mathrm{ml}$ which was above the normal range. The clinical and laboratory findings were pointing towards a large complex ovarian mass most probably of malignant potential, therefore decision for exploratory laparotomy was taken. On laparotomy an unexpected large hematosalpinx was found and the histopathological examination of the specimen showed chorionic villi confirming chronic ectopic pregnancy.

To sum up, there were many factors which led to the diagnostic dilemma in our case. Similar challenges can be faced by other clinicians working in set-up like ours. Therefore awareness about such rare cases can help us to broaden our clinical approach to save the precious life of the patient.

\section{CONCLUSION}

Chronic ectopic pregnancy can be quite intriguing with rare clinical presentation such as a large hematosalpinx and sometimes features mimicking that of an ovarian tumor. The investigations often mislead us and create biased opinion. Also the paucity of resources restricts clinical approach. However awareness about such rare cases is helpful in future clinical practice.

\section{Funding: No funding sources \\ Conflict of interest: None declared \\ Ethical approval: Not required}

\section{REFERENCES}

1. Cole T, Corlett RC Jr. Chronic ectopic pregnancy. Obstet Gynecol. 1982;59:63-8.

2. Uğur M, Turan C, Vicdan K, Ekici E, Oğuz O, Gökmen O. Chronic ectopic pregnancy: a clinical analysis of 62 cases. Aust NZ J Obstet Gynaecol. 1996;36:186-9.

3. Bedi GD, Moeller D, Fagan CJ, Winsett MZ. Chronic ectopic pregnancy. A comparison with acute ectopic pregnancy. Eur J Radiol. 1987;7:46-8.

4. Saatli B, Yıldırım N, Çağlıyan E, Obuz F, Koyuncuoğlu M. What is your diagnosis? J Turk Ger Gynecol Assoc. 2013;14(2):123-4.

5. Subramanyam BR, Raghavendra BN, Balthazar EJ, Horii SC, Hilton S, Goldstein SR. Hematosalpinx in tubal pregnancy: sonographic-pathologic correlation. AJR Am J Roentgenol. 1983;141(2):361-5.

6. Nacharaju M, Vellanki VS, Gillellamudi SB, Kotha $\mathrm{V}$, Alluri A. A rare case of chronic ectopic pregnancy presenting as large hematosalpinx. Clin Med Insights Reprod Health. 2014 Jan;8:1-4.

7. Hunter CL, Ladde J. Molar pregnancy with false negative $\beta$-hCG urine in the emergency department. West J Emerg Med. 2011 May;12(2):213-5.

8. Sindos M, Wang TF, Pisal N, Eben F, Singer A. Bilateral hematosalpinx in a case of ectopic pregnancy: a clinical dilemma. Am J Obstet Gynecol. 2003;189(3):892-3.

DOI: $10.18203 / 2320-1770 . i j r \operatorname{cog} 20150129$

Cite this article as: Tigga MP, Chakraborty SB, Ray J, Debbarma S, Debbarma A. A rare case of chronic ectopic pregnancy mimicking ovarian tumor: a diagnostic dilemma. Int J Reprod Contracept Obstet Gynecol 2015;4:918-20. 